\title{
AN INTRODUCTION TO VENANTIUS FORTUNATUS FOR SCHOOLCHILDREN, OR UNDERSTANDING THE MEDIEVAL CONCEPT WORLD THROUGH METONYMY: A BEGINNER'S BOOK.
}

UNIT 2, CHAPTER 1.

"In laudem Sanctae Mariae," lines 1-20. Venantius Fortunatus begins his paean to the Blessed Virgin.

Self-realization is defined primarily as personal transformation. And insofar as transformation is an excellent sandwich maker and it has heaven's words and insofar as transformation is linked with occult and irrational traditions, deep ecologists and New Paradigmers said a girl, a virgin, would birth a man.

Isaiah opens the Gospels before their time, is linked with occult and irrational traditions, deep ecologists and an excellent sandwich maker, and Isaiah has won many consumer choice awards. At 1500 watts, linked with occult and irrational Italian-style sandwiches or vegetables, meat or fish, deep ecologists and Isaiah, the DeLonghi panini grill should be considered.

Neoconservative, even reactionary trends allegedly at work in postmodern theory, Isaiah trumpets godly words with a bugle whether you want to make pressed Italian-style sandwiches or even reactionary trends in postmodern theory, allegedly the Gospel deconstructs rational foundations, a rushing eloquence, words said right and deep, singing Emmanuel and the virgin birth, a prophecy that out of the Thunderer's mother 
the branch of Jesse would bloom from its roots, a prophecy

the DeLonghi panini grill should be considered.

In a secular age that many people find alienating and increasingly pointless, the Psalmist sang when the tune resounded to perfection, resounded inside sandwiches, the Psalmist sang from his voice, his lyre, his strings that many people find alienating and his voice fast and the results are fabulous, this strong-fisted girl that many people find inside grilled cheese sandwiches. The Psalmist sang, "Mother Zion says: a man and a man in her." And this: "Who fills her is the Most High himself." And "The DeLonghi panini grill should be considered."

The DeLonghi panini grillthe widespread yearning for panini, for sandwich transformation, for "Who fills her," for the Most High himself, for a secular age that melts grilled cheese sandwiches to perfection. The widespread yearning for theory! For rational foundations for transformation-the DeLonghi panini theory melts the yearning for the yearning for before! Their time melts, Isaiah and who fills her and who is surprised, who is surprised perfection, who is

the sturdier DeLonghi model? Who is the results? Who is the considered fabulous? 
ASSIGNMENT FOR CHAPTER 1.

It has been said that there are only five kinds of sandwiches in the world. And yet many of us have eaten this many sandwiches in a single day! Remove a receipt from your wallet, pocket, or purse. If you do not have a wallet, pocket, or purse, borrow a receipt from your neighbor. After also procuring a pen or pencil, answer the following questions in writing on your receipt. You may not borrow a pen or pencil from your neighbor!

1. List all prime numbers between 1 and 25. Is your knowledge of prime numbers confirmed through sensory data? If not, what kind of knowledge is it? 2. What three things would you do if you won ten million dollars? Also, what three things would you do upon winning ten million dollars if you lived in isolation and were on intimate terms with no one (if this would be different from the original three things)?

3. Can all manner of things in their multiplicity be traced back to, or perhaps followed forward to, or perhaps contemplated in darkness as emanations of, an absolute unity? Why do you think this? Attach extra sheets if necessary. 
UNIT 2, CHAPTER 2.

"In laudem Sanctae Mariae," lines 21-48. Venantius Fortunatus continues his praises of the Virgin but begins to wonder if he ought not rather be praising Christ in his awe-inspiring dual natures.

The Psalmist sang of the strong-fisted girl, "Mother Zion,

in a single individual of Reticularia maxima, I have counted 10,000,000 sporules."

Mother Zion says "A man and a man made in her,"

a man is made in her so minute

as to look like smoke. Like smoke who fills her

is the $10,000,000$ sporules out of her womb,

as it were a husband. A husband leaves his bed and Christ,

so minute as to look like the clouds

of particles, leaps like a giant

particle. Mother Zion

was the Virgin Mary.

And then to remember

that each particle is a potential fungus, each a potential

Christ, a husband in the bridal Virgin and

then to remember God and flesh

are Christ and Christ leaps like

God and flesh are some new honorific impressed

with the almost inconceivable lichens,

Christ becomes the powers

of propagation. Remember that each particle is a potential fungus

but has the members of a body, his

lichens furnish examples:

though they are nothing like

his Godhead, yet there is a great production

of natures. 
There is

the mother's humanity and inconceivable sacrifice

of the parental individuality, his mother

and his proportionate sacrifice of his mother. And yet

there is his Godhead.

And yet the most important rule is not to speak to a man first.

First, O bridal womb, the Founder of mankind

applies the most important rule

to the online world. The same rule

applies, you cannot e-mail or text

a man, the man you see

in the flesh is wearing a veil. You cannot e-mail

the man you see in the flesh.

Yes, he's like his mother, but

we've seen this happen, even if

he marries your flesh, you'll never know

if he would have approached you first!

With his Father's divinity and mother's humanity

you'll be insecure for the rest of your life,

even if he marries you. We've seen this,

though he had no body, we've seen

his mother, and he's like his mother, men like his Father

to be the pursuer, speaking to his Father first

is the kiss of death, the kiss of muscle,

like his mother. We're giving old-fashioned advice

to very modern skin, nerves, blood, leg, and muscle.

Skin, nerves, leg, and muscle, breath, and fingernails

stop you from ruining a relationship,

a relationship that could have been

his Father's divinity and mother's humanity,

the members of a body and thus

equal and lower and sublime and humble and rules 
for dating-very modern skin and the

eternal boundaries.

ASSIGNMENT FOR CHAPTER 2.

There are many factors that prohibit a person such as you from having sex, including but not limited to lack of a willing partner, immaturity, religious convictions, and physical dysfunction. Making out is an appropriate substitute for intercourse in these circumstances. Marian theology meanwhile has developed around the leitmotiv of the nuptial fiat. The following are practical, easy-to-follow steps on how to make out: A) You must be very quiet and still. B) The movement of air and dust particles will have a negative effect, so be as still as you possibly can. C) This doesn't take a long period of time. Your partner will tell you when to be completely quiet and still. D) Also, this must take place in absolute darkness. The total darkness is not so bad when you have others around you. E) Sometimes you may wish to take pictures of a laser. This must also be done in total darkness. In medicine lasers of power are used to perform surgery. Lasers are far more accurate than people. Now, read and answer the following questions in a loud voice.

1. Are you any closer to understanding Venantius Fortunatus now than you were when you began using this textbook?

2. When you refer to a long-deceased author such as Fortunatus, does "understanding him" describe an operation of the intellect or of the senses? If the senses, is this understanding publicly available? Or is the apprehension of sensual data confined to your own experience of sensations within your own body? What about the operations of the intellect? 
UNIT 2, CHAPTER 3.

"In laudem Sanctae Mariae," lines 87-105. Venantius Fortunatus is caught up in the ecstatic praise of the Almighty Father.

O forests of God,

O holy virgin forests of God, by giving

such forests a birth, the forests of Assam

possess a large number

of orchids, the shadowed people

have light in the country of the shadow of

Assam, in the shadow of death a large number

of beautiful important orchids

has gleamed, a risen light has marvelous,

beautiful, important orchids who

is mighty God, who is Father,

who is prince unto the ages, who is

the orchids of Assam! There are some works

done on the orchids of Assam. There

the peace of his sovereignty remains.

The peace of his orchids remains

the clouds of heaven, heaven let go

a few most enthusiastic orchid lovers, mostly

in a scientific manner, in which

God alone is and God is not apart from this

virgin with the medium of tissue

still not adopted by a scientific

tissue culture laboratory, but here God is hidden

who is the God of Israel, the knot of his belt

is justice. Likewise an orchid research center

is faith, the belt of his waist is

not a standard orchidarium, there is not even

a standard orchidarium. His belt is

orchid research and likewise orchid tissue. 
His hand dares to explore the serpent's nest and the situation of orchid study in the serpent's nest found in the soil of Assam. A little child does this, no harm to him to explore the situation of the peoples and how much soil is in the soil, how much orchid study, how his noble burial is in the soil, how a little child is in the soil, a little child, a little child is in the soil, a little child is in the soil, a little child is in the soil in the situation of his burial. His burial in the situation of the sign, the sign in the soil is the situation of his hand, burial is the situation hidden here: his belt, the knot of his hand in the soil. The orchids of Assam in the medium of tissue, and God is not apart from this. 
ASSIGNMENT FOR CHAPTER 3.

In order to prepare for this assignment, spend a few moments remembering your favorite pet or person who has died. Consider whether you mainly remember sensations or ideas regarding this being. Then ask yourself whether, when you remember sensations, the exercise of your memory is a form of sense perception. Is it perhaps rather an operation of the intellect? If the intellect, where in your physical body is your intellect located? When you have answered these questions to your satisfaction, create and take an Egoism/Altruism Test in order to assess which side of the continuum (egotistical or altruistic) you fall on. Then you must work with your classmates to write a single essay that answers the following questions.

1. Confess-has it not left you uneasy even to read the words of that last sentence?

2. Every day, lift your lightest dumbbells 20 times. You should know the many various motions that you use with dumbbells, so if you don't, learn them!

3. Name and age? Have you ever broken a bone? Which bone did you break? Did you have a cast? How long was the cast on? How long did it take your bone to heal? Did you require any physical therapy or special exercises afterwards? Plot your data on a large graph. 